\title{
Urban morphology and the post-industrial city: commercial space in Manchester
}

\author{
Eamonn Canniffe \\ Manchester School of Architecture, UK \\ e.canniffe@mmu.ac.uk
}

\begin{abstract}
The contemporary post-industrial city has developed within a system where every square metre of its area might be assessed for its economic productivity and market value. Retail space, leisure space, even public open space, as well as housing and work environments are quantifiable and comparable in financial terms as the ultimate test of their value. This conception of urban space as units of capital has its origins in the industrial development of centres such as Manchester where, largely unencumbered by earlier urban patterns, the idea of the modern city could thrive. As a 'shock city' Manchester, during the peak of its industrial growth in the early nineteenth century was an object of fascination and repulsion to the visitors it attracted. Opinion and rhetoric dominated social, economic and political debate, but dispassionate spatial analysis was rare. In the view of contemporary authors the town had few significant public spaces, instead being largely comprised of the vast industrial structures that crowded around the roads and canals. The mills were assessed for legal and insurance purposes, however, at a time of rabid competition and the prevalence of industrial accidents. The surveys that have survived provide the first opportunities to assess these examples of new urban space. The image results of a settlement composed of a single type, the mill or warehouse. Ancillary structures, most especially the workers' housing did not merit recording. In these products of spatial calculation the Manchester mill can be seen to set the pattern both for the productive spaces of industry and the spatial framework of the contemporary city, where the public space is one of consumption rather than community. The supervised and privatised public space of the contemporary city finds its genius loci in the industrial typology of its commercial origins.
\end{abstract}

Keywords: laissez faire; Manchester; morphology; regeneration.

\section{To cite this article:}

Canniffee, E. (2016). Urban morphology and the post-industrial city: commercial space in Manchester. The Journal of Public Space, I(I), 53-62, DOI: I0.5204/jps.v liI.IO

This article has been peer-reviewed and accepted for publication in The Journal of Public Space. Please see the Editorial Policies under the 'About' section of the journal website for further information.

\section{cc) (9) \$}

This work is licensed under a Creative Commons Attribution - Non Commercial 4.0 International License. https://creativecommons.org/licenses/by-nc/4.0/ 


\section{'the Utopia of Bentham' \\ (Leon Faucher Manchester in 1844)}

The history of a city, even merely of the architecture of a city, can never present a definitive picture. When that city is itself in a self-conscious state of transition, with the apparent discarding of many traces of its own history and heritage as so much dross, one can seemingly be engaged on a particularly futile task to document that transition. Yet the recording and the assessing of such a recent phase as the two decades since 15 June 1996 when the city of Manchester suffered substantial physical damage to its commercial core seems worthwhile because the effects of the I.R.A. bomb on that date and the strategies (or lack of them) adopted in its aftermath were profound. The change in the visual appearance of the city, coinciding with transformations in urban policy which changed other northern English cities as well, represents the greatest rupture in the continuity of Manchester's urban development since the Second World War. (Rogers et al. 1999). On the near side of such a breach, with all context affected, it is often difficult to recall what it was like on the far side, in an industrial past the circumstances of which have clearly been abandoned forever. But we need to know why we are where we are to be confident that we know where we are going.

It was a salutary experience to observe the relatively low status of the built environment in Manchester's official repository of record. In 20I4, in the newly reopened Central Library, the Local History section's holdings on architecture in Manchester account for considerably less shelf space than the ghost-written biographies of local television celebrities, even only those associated with one particular long-running soap opera. The plain truth is that Manchester, in general, has little regard for its architecture and is only begrudgingly concerned with it. The literature on the subject of Manchester's architecture is sparse and, despite some academic interest, reflects a general lack of concern with the built environment (Parkinson-Bailey, 2000; Hartwell 200I). This is something of a paradox since the city is extremely aware of its image, and its architectural character, both historically and contemporaneously, is how the city represents itself to outsiders. It is the contention of this paper that this disinterest shown internally within the city, outside of the professions in architecture and the built environment, is the result of the history of its industrial development and the ruthless economic basis of its recent regeneration. The purpose of this paper is to explore some examples of how Manchester looks and is proposed to look, in its new buildings and public spaces, and how the promotion of the regenerated city seems at odds to the experience of residents and visitors alike. As an academic working in the city I am often asked by visiting colleagues to account for the discrepancy between the generally laudatory literature available and the somewhat disappointing reality that literature claims to represent (RIBA \& Manchester City Council 2004). It therefore seems important to provide an alternative account, partial, personal and maybe even provocative, which could help illuminate the puzzling reality of the city. The pattern that the early phase of industrialisation established, however, was one where production and its requirements took a clear lead over any aspect of life that was noncommercial, be that spiritual, cultural or even defined by concerns over social welfare. The significance of Manchester is less its endlessly rehearsed pre-eminence in industrialisation but rather the typicality of its experience and its rapid imitation by other towns and cities to which its global trade connected it. Despite its provincial location its 
rivals were, self-consciously, not the other British industrial centres but the cities of the states whose symbols adorned the painted ceiling of the Great Hall of Alfred Waterhouse's Manchester Town Hall completed in 1877. The scale of Manchester might be outstripped by other industrial centres in the later nineteenth century, but once she had her own global shipping route with the opening of the Manchester Ship Canal ( 1894) a new phase of expansion presented itself which it took the outbreak of the Great War to arrest. Other cities might prefer to see their own significance as resting on stronger cultural aspirations but Manchester's confidence rested on the firm foundation of its global commercial origins, and that attitude prevails to the present day.

The naked industrial environment of the growing town had been observed during Karl Friedrich Schinkel's English journey in 1826, which brought him into direct contact with the technological progress of Britain in many sites across the country. (Bindman \& Riemann, 1993) However, his small sketch of the mills of Ancoats, with crude brick mills stacked up like so many boxes by the side of the Ashton Canal brought an abrupt urban scene to the mind and eye of an architect whose oeuvre grew out of a theatrical attitude to the beautification of the Prussian capital of Berlin in which he was engaged. In the north west of England he was confronted with a shocking urban environment that owed nothing to images of Greece or Rome, or even the medieval period which was deemed quintessentially northern European in spirit. Here was a city in all but name that owed nothing from the real or imagined past but everything to the economic imperatives of the nineteenth century present. The finest architectural mind of his generation was at once fascinated and repelled, repelled enough to note that 'made from red brick for the bare necessity only, make a rather gloomy impression' but fascinated enough to take back to Berlin the germ of an idea which would be synthesised into the design of the Bauakademie (1832-36) and the customs warehouse, Packhof, (1829-3I) in Berlin. In Schinkel's Ancoats sketch, against the towering mills and the even taller factory chimneys and dwarfed by these brute examples of mechanical production, were the hovels in which the workers existed. Schinkel's pen, with a few strokes, suggested the hazardous nature of the dwellings, poorly built, lacking in weather tightness, barely lean-tos against the great sheer walls of the factories, the symbolic form of the industrial town.

An even more dehumanised representation exists in a manuscript survey (presumably for legal or insurance purposes) for the period circa 1822 'Plans of all the Spinning Factories in the Township of Manchester' which survives in the collection of the John Rylands Library in Manchester acts as an early study in industrial morphology, with numerous detailed examples (Walter, 1976). Take for example, the land owned by Roger Aytoun Esq. and occupied by Mr. Thackery in the neck of land between a bend of the River Medlock. Here a disparate group of one, two, three and four storey buildings illustrate the incremental nature of early industrial development. The presence on the plan of a 'Factory burnt down' adjoining the tallest structure indicates the ever present hazards of industrial development.

In contrast, the site occupied by Richard Rothwell positioned parallel to a canal and a 'New Street' was a single rectangular block the seven storeys of which, plus loft were proof of the rational possibilities of efficient design. What the plates in the manuscript fail to record is the presence of the factory workers, who simply do not figure, apart from the occasional references to a dwelling house, presumably occupied by a manager or overseer. At this date the factory owners were already living off-site, and the workers 
would have been living where they could, leaving a situation of unplanned zoning between wealthy districts, industrial areas and working class districts which Engels would document in subsequent decades (Engels (1844), 1987).

The urban morphology of the industrial environment was, of course, dependent on two distinct pressures, which still hold true today, external forces and internal logic. Externally the position of new structures within the town was a product of the availability of land and sources of power, generally watercourses for water and steam power in the initial phases of development. Navigable rivers and canals also provided an efficient means of transport. The internal logic was a product of, in the case of mills, the number of looms which could be powered from the energy source and the optimisation with which they could be serviced by their operators. The constructional limitations of cast iron and brick then came into play in what until the Factory Act of 1833, and other early pieces of legislation, was essentially unregulated development.

Notwithstanding the significance of internal industrial processes to the morphological development of Manchester the situations in adjoining areas within the city grew in quite distinct ways as a result of historical origins and circumstantial developments. In a survey carried out by English Heritage in $200 \mathrm{I}$ for example, under the subtitles 'An Outgrowth of Accident' and 'Built According to a Plan' the differing situations of Shudehill and the Northern Quarter areas were contrasted. In discussing the historical development of these districts (the latter only rebranded as such by Manchester City Council in 1993) the former adjacent to the medieval centre clearly continues to display the irregular street patterns and narrow plots despite industrial development having occurred there as long ago as 250 years. In the Northern Quarter in contrast there is regular grid planning in the area around Stevenson Square, laid out by the new land owner William Stevenson in 1780 in preparation for the northern wards expansion of the town. That street network has remained largely intact with most blocks occupied by nineteenth and early twentieth century warehouses and manufacturing buildings with grand frontages to major thoroughfares. This building stock would be readily convertible to use by design companies and residential development from the late 1990s to the late 2000s and indeed provide much of the architectural ambience of the fashionable NQ4 area. Shudehill's looser patchwork of smaller historical remnants, empty sites and anonymous contemporary residential developments surround significant pieces of transport infrastructure such as the Shudehill Interchange (lan Simpson / Jefferson Sheard, 2006). In microcosm the disparity between the survival of elements of the urban fabric in these two neighbouring areas betray much of the broader situation of Manchester as a whole, since curiously the area with the irregular plan and topography has seen more demolition for development than the one with more obviously commercial building plots.

What are the morphological constraints which might condition the present urbanity of development in Manchester and how might they be compared to the historic situation? The initial unifying factor might be deemed to be that the building obey only an internal logic of productive or lucrative space. The external factor of consistent height, which might have been subject to some control in the 1970s and 1980s is now seldom invoked as a cause to determine the exterior, indeed Manchester has no tall building policy. The maximising of building form positioned on the plot represents a return to the spatial model which was employed during the period of the 'shock city'. In that era the limits of engineering technology might modify the risk produced by creating more space to 
support more machinery but the speculative impulse of current city development provides few such rational limits. If you can borrow the money the building will be built, and this can be seen in recent developments such as Spinningfields and First Street and proposed developments such as St. John's Quarter and St. Michael's. Whether broader economic circumstances will then allow it to be let depends on the proliferation of that same mentality on neighbouring plots. This constraint is a phenomenon which is common to both the office and residential sectors in terms of the current market.

However the issue of external appearance is more clearly the subject of differences between the present city and the developing town. The typology of cast-iron structure and brick skins with regular openings, creating a uniform if monstrous townscape, has given way to an almost heedless variety of façade treatments. The notion of authenticity in architecture, perhaps always dubious, has been abandoned to an apparently random form of pattern making using façade systems which often bear no relation to internal use and everything to abstract external appearance. The freeing up of façade conventions which indicated positions of floor levels, which represented lines of structure or communicated anything other than wrapping, led to the ubiquity of the barcode façade and the frantic expression of individuality in building, appears to have become a key component in urban design. Double and triple skins of sealed units serve to divorce the occupiers from their contexts, especially in office environments. Conversely in the residential sector the ubiquitous motif is the balcony providing some space for external individual expression, but often because of their limited size reduced to little more than storage for the cramped apartments. Their existence, while providing some mark of individual inhabitation externally serves to emphasise the tentative nature of city centre dwellings represented by statement balcony furniture, the overcrowded storage area, or the abandoned balcony of the 'buy to leave' apartment i.e. unoccupied investment property bought by foreign buyers. The morphology of these small spaces reveals much about the nature of occupation in the overheated residential market in central Manchester.

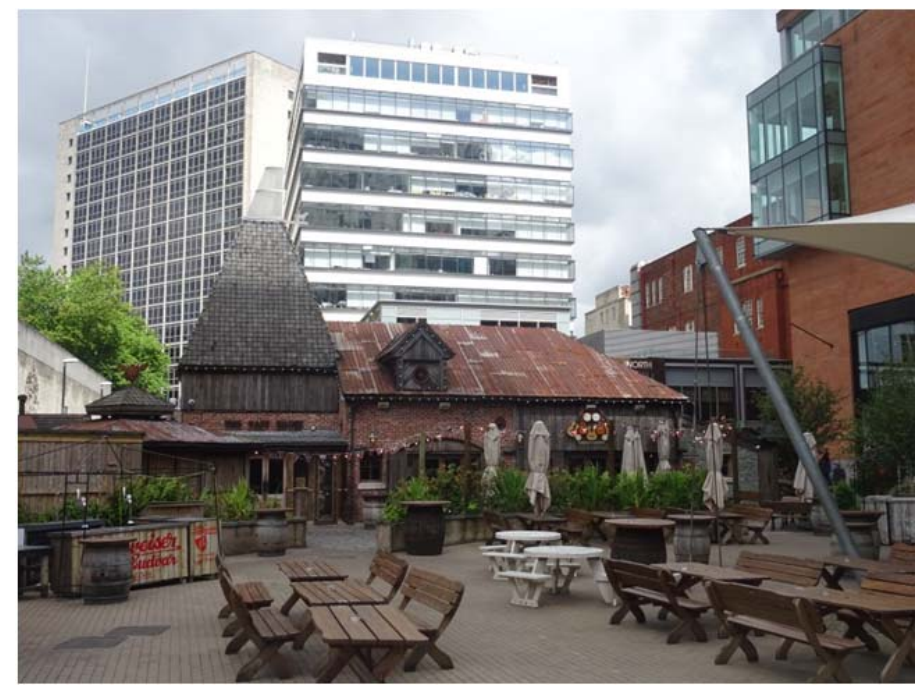

Fig. I. The Oast House, Spinningfields, Manchester 20II. Photo: Eamonn Canniffe 


\section{'the Spirit of materialism and indifference to beauty' (Rowland Nicholas City of Manchester Plan 1945)}

There is perhaps a contradiction in the drift of morphology in contemporary Manchester, although both tendencies are rooted in the same commercial origins but differentiated in the scale of operation. Clearly the bundling of adjacent plots to create ever larger single blocks operates as a process of consolidation and amplification at the building scale. At the same time, and apparently in the opposite direction of travel, the hollowing out of blocks to create privately owned public spaces would seem to be eroding the morphology of the city and causing a highly confused pattern to emerge.

Were Schinkel to arrive today in Manchester, what would be seen in Manchester that could hold his attention? Yes the mills of Ancoats, preserved now as monuments to vanished enterprise, Schinkel's own part in the evaluation and appreciation of the industrial structures being a component in the heritage impact narrative. He might draw instead a low and ramshackle hovel, sheltering beneath anonymous office buildings with no sense of connection but instead a strange co-dependency of purpose. The industrial workers have been replaced by office workers who live in the suburbs but require diversion and distraction which can be provided in a fake agricultural barn in an environment where no building is older than 1957. Schinkel's imagined sketch would depict The Oast House (Figure I) a piece of fictional heritage created in 20 I I on an empty site in a new business district in the city, Spinningfields. It is curious to speculate, whether this represents a falsification of urban history or its continuity in another guise. The mill owners of the early industrial period often used to dole out wages in public houses, which they also often owned, ensuring the dependence of the workforce whose wages would return to the paymaster. Today the urban economy is perhaps more complex but developments like Spinningfields make up the shortfall in return on investment by providing more and more places for drinking in what was planned before the economic crisis of 2008 as a work environment for the financial sector. (Canniffe 20I4).

Having endured a very deep recession in the period since the new business district's buildings began to be completed; the success of the development must be viewed as questionable. The residential component, the substantial wall of the Left Bank apartments, contains an unanticipated mixture of permanent residents, tenants of buy-to-let landlords, students and apartments let only at weekends for the growing stag and hen party trade. Some remain unoccupied having been bought as investments that, depending on the point in the economic cycle at which they were purchased, may or may not provide a good return. Several buildings were designed with the financial and banking sector in mind, which was particularly badly affected during the economic crisis. However, in 2014, with a limited amount of economic confidence returning, plans were announced for further construction at Spinningfields, with buildings planned for the empty site adjacent to the Civil Justice Centre, and the announcement that Quay House, a 1970s block adjacent to The Opera House on Quay Street was to be replaced by a new office building by lan Simpson. Unexpected assurances were made about the maintenance of the private open space used temporarily for film showings, the viewing of televised summer sporting events and Christmas ice-skating. The appropriation of seasonal leisure provision by corporate providers, their temporary adoption and factoring into future plans is indicative of a fair 
degree of fragility in economic prospects, especially following the unexpected result of the Brexit referendum in June 2016.

Of course the period of the 'shock city' and the recent past were both times when internal migration played a strong part. The factories of the early industrial revolution were essentially constructed independently from existing populations that grew dramatically to work in them. The living accommodation of the workers did not concern the manufacturers, only their convenient location for labourers to work the machines. The economically defined industrial structure would therefore be accompanied by spontaneous settlements (to adopt today's terminology) which would be unplanned and often remain unrecorded. Engels's description in The Condition of the Working Class in England remains a valuable and critical account of conditions though its tone is somewhat unsympathetic to the unfortunate inhabitants. While living conditions have improved beyond compare, the morphological changes in the recent history of Manchester bear some similarity in that they represent a formless accumulation of dwellings which test the limits of acceptability for their inhabitants, either in the meanness of their interior arrangements, or the sheer size and proximity of buildings squeezed on available construction sites, evident in three other ongoing projects in the city.

One might wearily predict that there will be more of this type of development to come in the extension of Allied London's land holdings across Quay Street on the former Granada Studios site. The St. John's Quarter in central Manchester is perhaps indicative of the drift of urban design practice in the city after nearly two decades of market-led urbanism. The departure of Granada Studios to MediaCity:UK in 2013 made thirteen acres of land available between Castlefield and Spinningfields. (It is a paradoxical situation that when many other regional cities are pinning their economic hopes on the attraction of media companies, the City of Manchester has lost the presence and activity of both the BBC and one of the largest independent companies to neighbouring boroughs). The developers Allied London purchased the site and announced that the newly designated St. John's Quarter would be a residential led development complementing their existing office development across Quay Street in Spinningfields.

In early 2014 the developers unveiled a series of masterplan proposals for the site by ten design practices, and also hosted a community consultation event inviting ' stakeholders' to contribute ideas. Having been an effectively closed site during Granada TV's tenure since the 1950s the local residential community are essential to engage in the process, those in the existing apartments who might be expected to want more green open space and other social amenities, and local businesses concerned about the impact of new development. They are currently presented with a very dense residential project based around pedestrian alleys, and a series of glass office towers lining the frontage to the River Irwell. Cultural activities are intended to be housed in a new multi-functional space called The Factory won in competition by OMA in 2015 and partly funded to the tune of $£ 78$ million by central government in a clear attempt to pump the prime commercial development of this district.

At First Street an over-dense development of mediocre quality can be traced to its origins, where a campus style office building was placed in the middle of cleared brownfield site in early 1990s, only to be radically modified and expanded and used as the determining factor for the grim new buildings and mean privately owned public space which now surround it. 


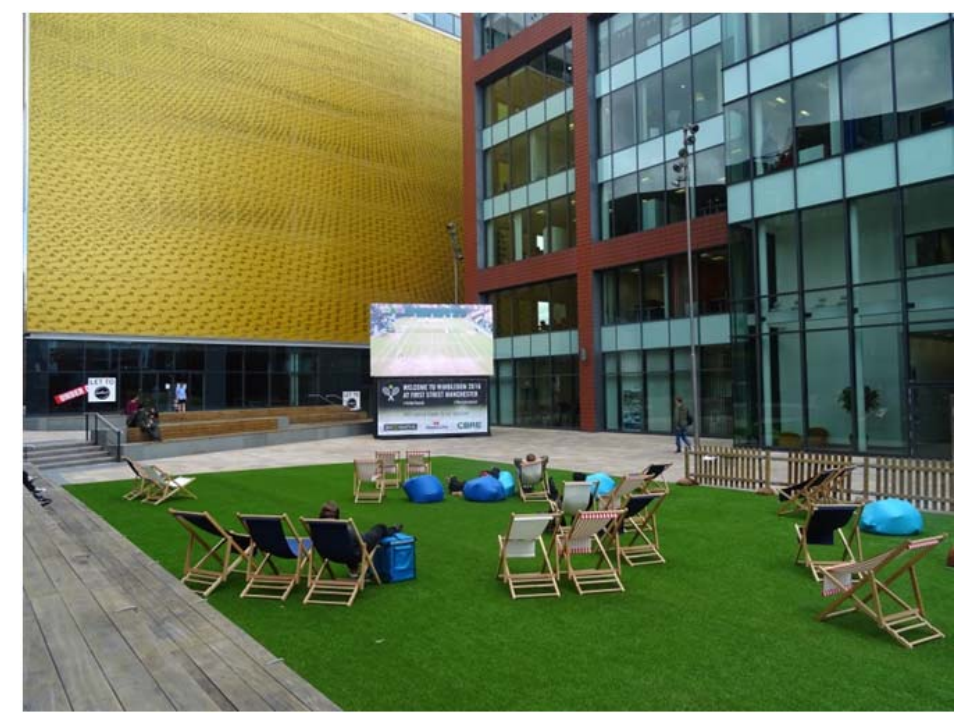

Fig. 2. Tony Wilson Place, First Street, Manchester. Photo: Eamonn Canniffe

The space itself, called with no hint of irony Tony Wilson Place, after the charismatic founder of the Factory Records label is under great pressure to earn its keep through monetisation via pop-up bars and temporary events, the activities which pass for the successful public realm in the characterless post-industrial city (Figure 2).

Spinningfields, St. John's and First Street largely effect former industrial sites, but in the thirst for development the civic core itself, is now threatened by over development. This tendency is exemplified by the proposal revealed in July 2016 for the redevelopment of a large block, called St. Michael's, mainly occupied by the redundant Bootle Street Police Station and the Manchester Reform Synagogue. What is at present a largely continuous perimeter block in an elongated rectangular form is set to have its form inverted by the introduction of a diagonal route between two black clad towers (designed by Make Architects) of $3 \mathrm{I}$ and $2 \mathrm{I}$ storeys respectively placed in a staggered arrangement on the site. The groundscape is advertised as new public space for the city, although it is effectively a partially covered commercial mall which negotiates a significant change of level, called in the enthusiastic local press Manchester's Spanish Steps. The enthusiasm is at least in part due to the leaders of the project being former Manchester United footballers Gary Neville and Ryan Giggs, this project one of a series of development projects which have brought the influence of the city's footballing wealth to bear on its urban form. In the long term this project poses a threat to the heritage amenity of the civic core, both because of the size of the two towers, but also the erosion of the street network's primary importance in this area of the city.

In the proposal, the north eastern corner of the block is left open to create a commercially active plaza intended to connect to Albert Square and Manchester Town Hall. However this new plaza is itself bounded on its southern edge by the shorter of the two towers, and therefore might be expected to be in shadow for much of the day and most of the year. A low pavilion attempts to provide some remnant of definition to the northern side of the plaza but appears to be only needed to mask the port cohere entrance to the larger tower. Given the need for drop off there and the inevitable delays, the street, Jackson's Row, which currently has a small amount of open space associated 
with the Synagogue, is likely to be reduced to a service zone, dominated as I will be by the lower storeys of the taller tower. The diagonal route, semi enclosed at its lower end before it connects to the plaza, is clearly intended to create a slice of mid-block townscape but will be essentially retail in character at the cost of severely compromising the life of the existing streets and their buildings, especially the historic Sir Ralph Abercromby pub which dates back to the industrial era and is currently proposed for demolition.

The general topographic situation of Manchester has offered little opportunity for the creation of dramatic urban ensembles and indeed the study of its history might suggest that such aesthetic sensibilities are alien to the genius loci. The city does contain notable individual works of architecture, but often placed in unsympathetic settings which diminished their apparent impact. However it is not beyond the collective imagination of the city to develop it with more of a sense of ambition and concern for its appearance. The city would have to adopt a physical plan which could be implemented over several decades. Such long term thinking has not been pursued since 1945, and the failure to fulfil that vision set the pattern for subsequent decades. It is, of course, an irony of history that the laissez-faire attitudes synonymous with Manchester liberalism in the nineteenth century are exactly at the root of the haphazard decisions regarding city planning which currently hold sway in Manchester. One can envisage three steps that could be undertaken to improve matters. One would be encouraging more transparency in the way decisions are made. The second would be adherence to some kind of standards for building height and volumetric expression which could impose a discipline on the more wayward proposals. And lastly an urban code could be developed over a five year period covering the whole of the city centre and treating it in a consistent manner derived from a close study of its morphology.

There is doubt in my voice mainly because what we see in Manchester's recent urban regeneration is so difficult to admire, presented through the marketing of the city as a great triumph over adversity, but in the experience of many visitors a completely generic experience providing a good range of international brands but increasingly few unique elements that might define urban quality. Quantity of buildings, of retail experiences and of anonymous spaces between them is the characteristics of the city which are being created.

\section{References}

Author unknown. c. (1822). Plans of all the spinning factories within the township of Manchester. Also some in which power looms are working, and a few occupied for other purposes, unpublished manuscript. John Rylands Library, Manchester.

Bindman, D.; Riemann, G. (1993). The English Journey: Journal of a Visit to France and Britain in 1826. New Haven and London: Yale University Press.

Canniffe, E. (20l4). Publoid space in the Microcosmopolis: two new business districts in Manchester and Salford, in M. Lansberger, M. Caja, M. Bovati, G. Floridi (Eds.). Cities in transformation. Padova: II Poligrafo, 199-206.

Engels, F. (I844) 1987. The condition of the working class in England. London: Penguin. 
Urban morphology and the post-industrial city: commercial space in Manchester

English Heritage. (200I). The Shudehill and Northern quarter area of Manchester 'an outgrowth of accident' and 'built according to a plan', English Heritage Architectural Investigation Reports and Papers B/066/200I.

Hartwell, C. (200I). Manchester: Pevsner architectural guides. New Haven, London: Yale University Press.

Parkinson-Bailey, J. (2000). Manchester: an architectural history. Manchester: Manchester University Press.

RIBA and Manchester City Council (2004). Manchester: shaping the city. London: RIBA Publishing. Rogers, R., et al. (1999). Towards an urban renaissance: final report of the urban task force. London: $E$. \& F.N. Spon.

Walter, E. V. (1976). New light on dark satanic mills, Communication, Vol. 22-3. 